\title{
Green Synthesis of Chitosan Based Copper Nanoparticles and their Bio-Efficacy against Bacterial Blight of Pomegranate (Xanthomonas axonopodis pv. punicae)
}

\author{
Chidanandappa $^{1^{*} \text { and V. B. Nargund }}{ }^{2}$ \\ ${ }^{1}$ Department of Plant Pathology, College of Agriculture, Dharwad, India \\ ${ }^{2}$ University of Agricultural Sciences, Dharwad-580 005, Karnataka, India \\ *Corresponding author
}

\section{A B S T R A C T}

Keywords

Chitosan-Copper

nanoparticles,

Xanthomonas

axonopodis pv.

punicae,

pomegranate aril

extract and

chitosan.

Article Info

Accepted:

15 December 2019

Available Online:

20 January 2020
A great interest towards investigating bactericidal properties of nanoparticles as an alternative to antibiotics has been initiated. Chitosan based nanoparticles (Ch-CuNPs) were prepared by use of water soluble chitosan solution $(1.0 \%)$ with $\mathrm{CuSO}_{4} .5 \mathrm{H}_{2} \mathrm{O}(10 \mathrm{mM})$ and pomegranate aril extract $(1.4 \%)$ under magnetic stirrer for $24 \mathrm{~h}$ at room temperature. The synthesized nanoparticles were characterized by Atomic Force Microscope (AFM) and Particle Size Analyzer (PSA) and tested for their antibacterial activity against pomegranate blight pathogen, Xanthomonas axonopodis pv. punicae. The average size of Ch-CuNPs was $89.39 \mathrm{~nm}$. The synthesized nanoparticles were evaluated against Xap with eight concentrations. The results revealed that, chitosan-CuNPs were effectively inhibited the growth of Xap at $1000 \mathrm{ppm}$ concentration and remained on par with standard antibiotic check streptocycline of $500 \mathrm{ppm}$.

\section{Introduction}

Nanotechnology is the study and application of extremely small things (1 - $100 \mathrm{~nm})$ and used across all the scientific fields, viz., chemistry, biology, physics, engineering, medicine, agriculture and related fields. The synthesis of metal nanoparticles is an active area of research in the field of nanotechnology. Several chemical, physical and biological methods have been used for synthesis of nanoparticles. However, chemical methods use toxic solvents, high-energy consumption and hazardous products. Thus, the focus has turned toward Green nanotechnology.

Copper compounds have been used as a 
biocide for centuries. Chitosan is a deacetylated derivative of chitin which is naturally present in the fungal cell wall and in crustacean shells from which it is easily extracted. It has been reported to possess antifungal and antibacterial activity and it showed to be effective against seed borne pathogens when applied as seed treatment (Orzali et al., 2017).

Pomegranate (Punica granatum L.) an important fruit crop of south India. Farmers faced a severe threat from bacterial blight disease and it reached alarming stage bringing substantial damage to the crop and heavy losses to the farmers (Benagi et al., 2012). Under epidemic conditions blight resulted in yield losses up to 80 per cent (Sharma et al., 2015 and Madhu, 2015). The disease prevailed in all the seasons with varying degree of severity.

Considering the experimental evidence and emerging research applications of nanotechnology in agriculture and plant pathological aspects, experiment was implemented on green synthesis, characterization of chitosan based copper nanoparticles and evaluation against disease caused by Xanthomonas axonopodis pv. punicae in pomegranate.

\section{Materials and Methods}

The synthesis and characterization of nanoparticles were carried out in Green Nanotechnology Laboratory and pathological experiments were carried out in the Department of Plant Pathology, College of Agriculture, UAS, Dharwad during 2017-18. The bacterial pathogen, Xanthomonas axonopodis pv. punicae (Xap) was isolated from the pomegranate leaves of Bhagava variety by standard tissue maceration isolation method. Pathogenicity of bacterial pathogen isolated from pomegranate leaves was confirmed by spraying the $48 \mathrm{~h}$ old cell suspension on to the susceptible pomegranate variety Bhagwa which were covered with polythene sheets to maintain more relative humidity $(>90 \%)$. Pure virulent culture was maintained on Nutrient Glucose Agar (NGA) media at $4{ }^{\circ} \mathrm{C}$ (Madhu et al., 2015).

Water soluble chitosan $(0.1 \mathrm{~g})$ was mixed in $100 \mathrm{ml}$ of water and kept overnight under magnetic stirrer. Copper sulphate $(10 \mathrm{mM}$ of $100 \mathrm{ml}$ ) of Himedia was prepared. Pomegranate aril extract $(1.4 \%)$ was used as reducing agent for copper sulphate $\left(\mathrm{CuSO}_{4} .5 \mathrm{H}_{2} \mathrm{O}\right)$. The synthesis protocol was slightly modified from Usman et al. (2013).

Reaction mixture consisting of copper sulphate + water soluble chitosan + pomegranate aril extract was kept under magnetic stirrer for $24 \mathrm{~h}$. Ch-CuNPs (metallic red) were settled at the bottom of the flask, collected by centrifugation @ 9000 rpm for 30 min and washed the pellets thrice by deionized water, then dried in hot air oven at $60{ }^{\circ} \mathrm{C}$ for overnight and stored in air tight bottles.

Dynamic light scattering (DLS) measurements was used for the measurement of average particle size of nanoparticles on high performance particle size analyzer Z3000 (Nicomp, USA). Diluted chitosan based copper nano particles (0.01 $\mathrm{g}$ of CuNPs suspended in $100 \mathrm{ml}$ of sterile distilled water) sonicated for $15 \mathrm{~min}$. for uniform distribution of nanoparticles. Then $3 \mathrm{ml}$ of sonicated $\mathrm{Ch}$ CuNPs were placed in disposable polystyrene cuvettes, analyzed at room temperature in triplicate at a scattering angle of $90^{\circ}$ and the results are given as the average particle size. Topography of Ch-CuNPs was done using Atomic Force Microscope (AFM) (NanosurfAG, Swiss, Flex AFM, with 24 bit C3000). Sonicated Ch-CuNPs were coated on mica sheet and allowed to dry for $15 \mathrm{~min}$ under room temperature, kept overnight under 
hot air oven at $70{ }^{0} \mathrm{C}$ then again sample was kept under room temperature for $10 \mathrm{~min}$. Analysis was done by using Nanosurf Reporter software.

Characterized Ch-CuNPs were evaluated against bacterial blight of pomegranate caused by Xanthomonas axonopodis pv. punicae (Xap) at 1-4,000 ppm concentrations by standard paper disc assay for in vitro and foliar spray method for glasshouse evaluation. Loop full of ( $72 \mathrm{~h}$ old) of Xap culture was multiplied on nutrient broth. Solution of 200 $\mu \mathrm{l}$ was spread on nutrient glucose agar.

Sterilizing filter paper discs (Whatman No. 1) measuring $6 \mathrm{~mm}$ diameters were soaked for 10 min in 1-4,000 ppm of CuNPs and placed on the surface of media seeded with Xap culture. The sterilized filter paper discs were dipped in sterilized water/ plant extract served as control. Streptocycline @ 500 ppm used as a standard check. The inoculated Petriplates were incubated at $27 \pm 1{ }^{\circ} \mathrm{C}$ for $48 \mathrm{~h}$. Three replications were maintained for each treatment.

Observations were recorded by measuring the diameter of the inhibition zone around the filter paper disc for each treatment including control and standard antibiotic check streptocycline (500 ppm). Pomegranate plants (Bhagva) were spray inoculated with Xap, then covered with polythene sheet for $48 \mathrm{~h}$ for disease development.

Ch-CuNPs were evaluated against Xap causing bacterial blight of pomegranate by spraying of nanoparticles at onset of disease. Three replications were maintained for each treatment. They were incubated for 25 days and observations were recorded as per the scale (Anon., 2014). Further, these scales were converted into Per cent Disease Index (PDI) by using formula given by Wheeler (1969).

\section{Results and Discussion}

Bio-synthesis of nanoparticles from chitosan and plants are pertained under green nanotechnology. Main aim of green nanotechnology is to avoid the hazardous or toxic chemicals during synthesis of nanoparticles. Copper is one of the major antimicrobial compound used for the management of bacterial and fungal diseases of crop plants. When copper compounds are converted to nano size, they may enter the plant system and manage the fungal and bacterial plant pathogens in better manner.

In the present investigation chitosan based CuNPs were synthesized by using chitosan and aqueous extract of pomegranate arils. Copper nanoparticles were synthesized by using water soluble chitosan and aqueous extract of pomegranate aril extract with slight modification of protocol (Usman et al., 2013). This resulted in smaller sized nanoparticles (89.39 nm).

Pomegranate aril is rich source of polyphenols, vitamins, esters and flavonoids. Hence, it acts as reducing and stabilizing agents for the bio-reduction reaction in to nanoparticles (Ahmad and Sharma, 2012). Change in color from sky blue to dull green was preliminary indication of $\mathrm{Ch}-\mathrm{CuNPs}$ formation.

Chitosan based CuNPs were characterized by particle size analyzer. The average smaller size of Ch-CuNPs was found to be $89.36 \mathrm{~nm}$ (Fig. 1). CuNPs were synthesized by reduction reaction in a microwave oven results average particles size of $200 \mathrm{~nm}$ (Sastry et al., 1997, Chikkanna et al., 2016 and Nargund et al., 2017). 
Table.1 In vitro evaluation of Ch-CuNPs against $X$. axonopodis pv. punicae

\begin{tabular}{|c|c|c|c|}
\hline $\begin{array}{l}\text { Treatment } \\
\text { No. }\end{array}$ & Treatment & $\begin{array}{l}\text { Conc. } \\
\text { (ppm) }\end{array}$ & $\begin{array}{l}\text { Inhibition Zone of } \\
\text { Xap at } 48 \mathrm{~h}\end{array}$ \\
\hline 1 & \multirow{10}{*}{ Ch-CuNPs } & $1-250$ & $0.00(1.00) *$ \\
\hline 2 & & 500 & $0.00(1.00)$ \\
\hline 3 & & 750 & $0.00(1.00)$ \\
\hline 4 & & 1000 & $6.33(2.71)$ \\
\hline 5 & & 1500 & $7.00(2.83)$ \\
\hline 6 & & 2000 & $7.33(2.89)$ \\
\hline 7 & & 2500 & $7.67(2.94)$ \\
\hline 8 & & 3000 & $8.00(3.00)$ \\
\hline 9 & & 3500 & $9.33(3.21)$ \\
\hline 10 & & 4000 & $9.67(3.27)$ \\
\hline 11 & $\begin{array}{l}\text { Pomegranate aril } \\
\text { extract }\end{array}$ & 14,000 & $0.00(1.00)$ \\
\hline 12 & $\begin{array}{l}\text { Water } \\
\text { chitosan }\end{array}$ soluble & 10000 & $0.00(1.00)$ \\
\hline 13 & $\mathrm{CuSO}_{4}$ & 4,000 & $5.23(2.30)$ \\
\hline 14 & Streptocycline & 500 & $16.33(4.09)$ \\
\hline 15 & Control & - & $0.00(1.00)$ \\
\hline \multicolumn{3}{|l|}{ S.Em. \pm} & 0.05 \\
\hline \multicolumn{3}{|l|}{ C.D. $(1 \%)$} & 0.20 \\
\hline
\end{tabular}

Table. 2 In vivo evaluation of $\mathrm{Ch}-\mathrm{CuNps}$ against pomegranate bacterial blight in glasshouse

\begin{tabular}{|l|l|c|c|}
\hline $\begin{array}{l}\text { Treatment } \\
\text { No. }\end{array}$ & Treatment & Concentration $\mathbf{( p p m )}$ & $\begin{array}{c}\text { Per cent Disease Index } \\
\text { (25 DAS) }\end{array}$ \\
\hline $\mathbf{1}$ & \multirow{2}{*}{ Ch-CuNPs } & 100 & $30.50(33.53)$ \\
\hline $\mathbf{2}$ & & 250 & $29.00(32.58)$ \\
\hline $\mathbf{3}$ & & 500 & $28.02(31.38)$ \\
\hline $\mathbf{4}$ & & 750 & $26.07(30.70)$ \\
\hline $\mathbf{5}$ & & 1000 & $24.00(29.33)$ \\
\hline $\mathbf{6}$ & & 1500 & $19.33(26.07)$ \\
\hline $\mathbf{7}$ & & 2000 & $16.00(23.57)$ \\
\hline $\mathbf{8}$ & & 2500 & $9.57(18.02)$ \\
\hline $\mathbf{9}$ & & 3000 & $7.82(16.23)$ \\
\hline $\mathbf{1 1}$ & & 10000 & $27.48(31.51)$ \\
\hline $\mathbf{1 2}$ & Water soluble chitosan & 2000 & $12.00(20.26 \mathrm{~s})$ \\
\hline $\mathbf{1 3}$ & CuSO & 500 & $6.00(14.15)$ \\
\hline $\mathbf{1 4}$ & Streptocycline & - & $31.33(34.04)$ \\
\hline S.Em. $\mathbf{\pm}$ & Control & & 0.48 \\
\hline C.D. $(\mathbf{1} \%)$ & & & 1.84 \\
\hline
\end{tabular}

* Values are the parenthesis are Arcsin transformed values $\sqrt{\boldsymbol{x}+1}$ 
Fig.1 Characterization of chitosan based copper nanoparticles by Particle Size Analyser $(89.39 \mathrm{~nm})$

NICOMP SUMMAPY:

Peak \#1: Mean Diam. = $12.0 \mathrm{~nm}$, S.Dev. $=1.5 \mathrm{~nm}$ (12.9\%) Intens. $=13.0 \%$

Peak \#2: Mean Diam. - $77.4 \mathrm{~nm}$, S.Dev. $12.7 \mathrm{~nm}$ (16.4\%) Intens. $-87.0 \%$

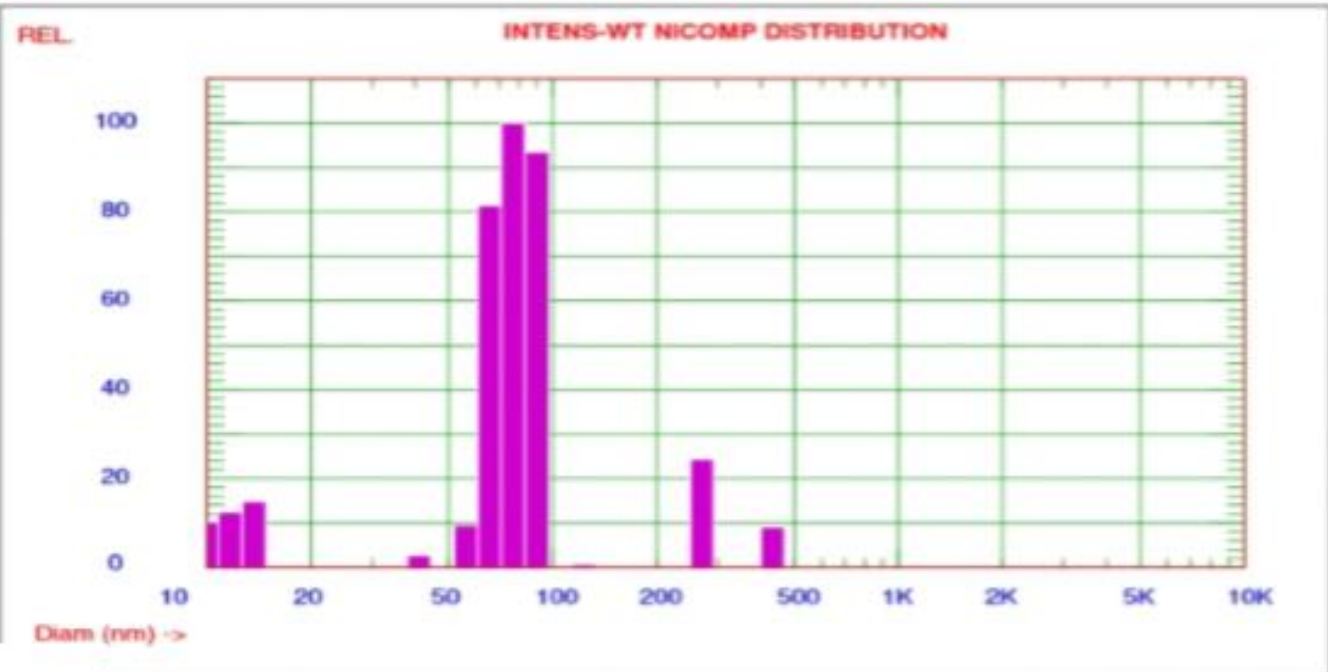

Fig.2 Chitosan based copper nanoparticles under atomic force microscope

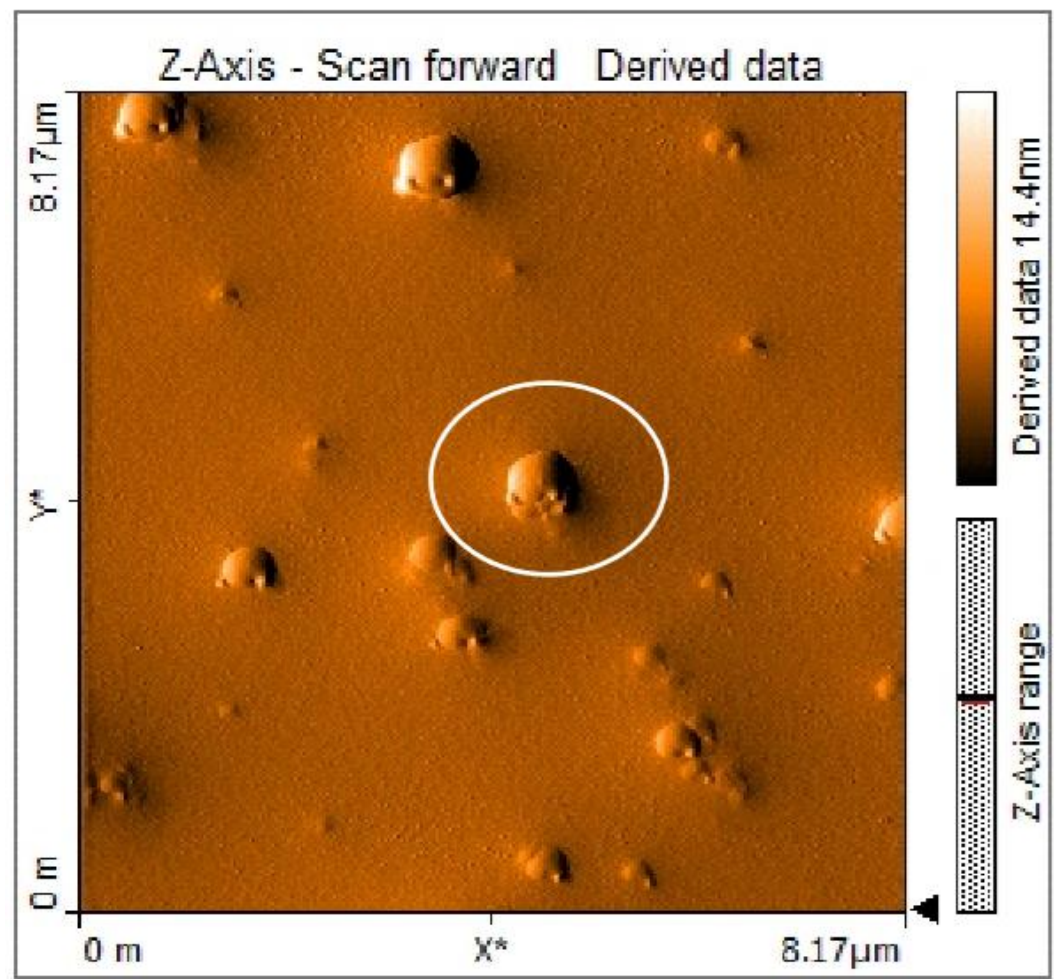


Fig.3 In vitro efficacy of chitosan based copper nanoparticles against $X$. axonopodis pv. punicae
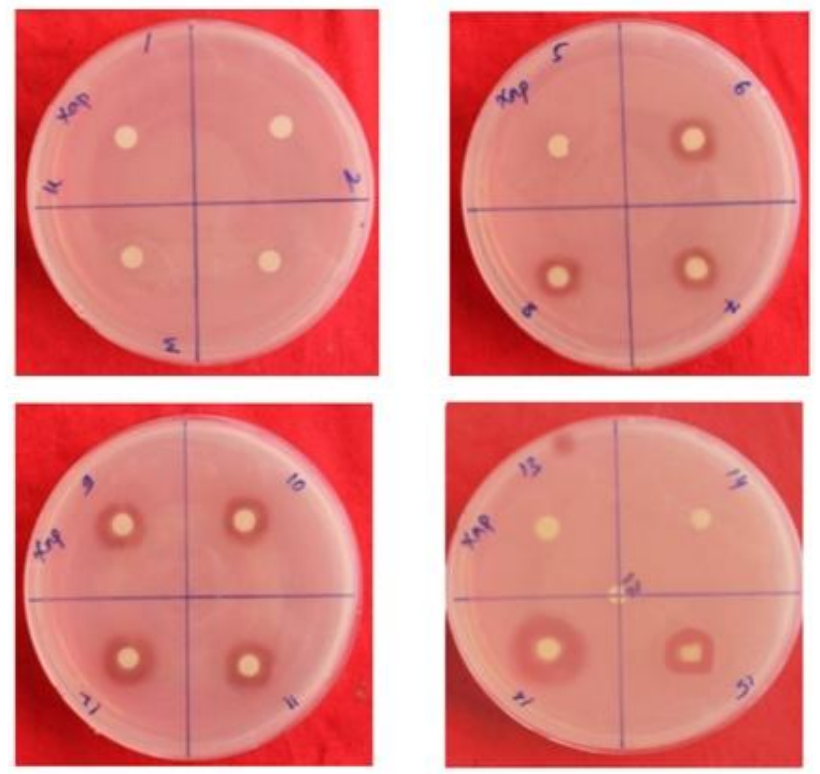

1) $100 \mathrm{ppm}$ 2) $200 \mathrm{ppm}$ 3) $250 \mathrm{ppm}$ 4) $500 \mathrm{ppm}$ 5) $750 \mathrm{ppm}$ 6) $1,000 \mathrm{ppm}$;) $1,500 \mathrm{ppm}$; 2 2,000 ppm 9) 2,500 ppm 10) 3,000 ppm; 11) 3,500 ppm 12) 4,000 ppm 13) PAE 14,000 ppm; 14) 10,000 ppm 15) CuSO 4,000 ppm 16) $500 \mathrm{ppm} ; 17)$ Water (control)

Ch-CuNPs in the present investigation was found to be in the size of $20-95 \mathrm{~nm}$ with spherical to irregular shapes which were observed under AFM (Fig. 2).

The present findings are in accordance with Nargund et al. (2016), who synthesized the copper nanoparticles from eucalyptus leaves and pomegranate pericarp then characterized by AFM which revealed the sizes ranging from 35-50 nm. Sampath et al. (2014) synthesized the copper nanoparticles in the form of bud shaped using Polyvinylpyrrolidone, L-ascorbic acid and copper sulphate and found to have sizes 6.41 $\mathrm{nm}$ in AFM.

Chitosan based copper nanoparticles were evaluated against Xap under in vitro by standard paper disc method. Ch-CuNPs showed inhibition of growth of bacteria from 500 ppm onwards. Highest zone of inhibition was observed in standard antibiotic check streptocycline $(16.33 \mathrm{~mm})$ followed by $\mathrm{Ch}$ -
CuNPs at 4,000 ppm (9.67 mm) and 3,500 ppm (9.33 mm) (Table 1 and Fig. 3).

The present results are in agreement with the work of Angrasan and Subbaiya (2014) who reported the antibacterial activity of CuNPs against Escherichia coli, Staphylococcus aureus, Bacillus substilis, Salmonella typhi and Klebsiella pneumonia. Efficacy of nanoparticles or any fungicides varied from lab to glasshouse and field experiment is mainly due to environmental factors which play vital role. So, in the present investigation, nanoparticles which showed significant efficacy under in vitro condition were tested in glasshouse condition for their efficacy on pomegranate plants.

The minimum severity of bacterial blight of pomegranate was recorded in streptcocycline500 ppm followed by Ch-CuNPs (3,000 ppm) and $(2,500 \mathrm{ppm})$ and copper sulphate with PDI of 5.00, 8.67, 9.63 and 15.83 respectively. The maximum disease severity 
(29.33 PDI) was observed in untreated control (Table 2).

The present investigation on chitosan based synthesized CuNPs were effectively enhanced their properties compared to bulk material. Hence it is the first report there is no such reports are published on efficacy of ChCuNPs against pomegranate bacterial blight under glasshouse conditions.

In conclusion, green nanotechnology is one of the most emerging research areas in the field of plant pathology from diagnosis to management of plant diseases by various innovative techniques. Ch-CuNPs were synthesized from water soluble chitosan with aqueous extract of pomegranate aril showed very good antibacterial activity. Hence ChCuNPs were best alternative to antibiotics or add supplementary effect to the antibiotics to manage the bacterial diseases of crop plants.

\section{References}

Ahmad, N. and Sharma, S., 2012. Green synthesis of silver nanoparticles using extracts of Ananas comosus. Green and Sustainable Chemistry, 2(4): 141-149.

Angrasan, J.K.V.M. and Subbaiya, R., 2014. Biosynthesis of copper nanoparticles by Vitis vinifera leaf aqueous extract and its antibacterial activity. Int. J. Curr. Microbiol. App. Sci., 3(9): 768-774.

Anonymous, 2014. Survey methodology for bacterial blight of pomegranate, $N C R P$ publication, p. 14.

Benagi, V.I., Ravikumar, M.R. and Nargund, V.B., 2012. Threat of bacterial blight on pomegranate im India - Mitigation by an integrated approach. II Int. Symp. on the Pomegranate. pp.113-116.

Chikkanna, S., Nargund, V.B., Hegde, R.V. and Hebsur, N.S., 2016. Synthesis of copper nanoparticles from mango leaves extract and their sensitivity studies on chilli seedlings. Proc. Int. Conf. on Nanotechnol. Visvesvaraya Tech. Univ. Chikkaballapura (India), p. 212.

Madhu S. Giri, 2015. Studies on induced resistance in pomegranate against bacterial blight pathogen Xanthomonas axonopodis pv. punicae. Ph. D. Thesis, Univ. Agric, Sci., Dharwad.

Nargund, V. B., Chikkanna, S., Mahesha, H.S., Vinay J.U., Srikan H.N. and Chidanadappa, 2017. Green nanoparticles: synthesis and application in plant disease management. Proc. Nation. Symp. on Emerging Trends in Plant Health Management in Relation to Climate Change, 12-13, September, Coll. Hrt. Bengaluru (India), p. 102.

Nargund, V.B., Chikkanna, S., Vinay, J.U. and Hasansab, A.N., 2016. Copper and sulphur green nanoparticles in plant disease management. Proc. Nation. Symp. on Rec. Adv. Pl. Health Management Sust. Prod., 15-16, December, UAS, Dharwad (India), p. 134.

Orzali, L., Corsi, B., Forni, C. and Riccioni, L., 2017. Chitosan in agriculture: a new challenge for managing plant disease. Biol. Act. App. Marine Polysaccharide. 17-36.

Sampath, M., Vijayan, R., Tamilarasu, E., Tamilselvan, A. and Sengottuvelan, B., 2014. Green synthesis of novel jasmine bud-Shaped copper nanoparticles. $J$. Nanotech., http: //dx. doi. org/10. 1155/2014/626523.

Sastry, M., Mayya, K.S. and Bandyopadhyay, K., 1997. pH dependent changes in the optical properties of carboxylic acid derivatized silver colloidal particles. Coll. Surfaces A: Physicochemical Engineering Aspects, 127(1-3): 221228.

Sharma, K.K., Sharma, J. and Jadhav, V.T., 2015. Recent developments in bacterial blights of pomegranate and its 
management, In: Recent Advances in the Diagnosis and Mgt. Pl. Dis., Springer, New Delhi, pp. 80-96.

Usman, M.S., El Zowalaty, M.E., Shameli, K., Zainuddin, N., Salama, M. and Ibrahim, N.A., 2013. Synthesis, characterization and antimicrobial properties of copper nanoparticles. Int. J. Nanomed., 8: 4467-4479.

Wheeler, B.E.J., 1969. An Introduction to Plant Diseases, John Wiley and Sons Limited, London.

\section{How to cite this article:}

Chidanandappa and Nargund, V. B. 2020. Green Synthesis of Chitosan Based Copper Nanoparticles and their Bio-efficacy against Bacterial Blight of Pomegranate (Xanthomonas axonopodis pv. punicae). Int.J.Curr.Microbiol.App.Sci. 9(01): 1298-1305.

doi: https://doi.org/10.20546/ijcmas.2020.901.143 